\title{
Analysis of the Economic Influences of the Investments in China
}

\section{from Transnational Corporations}

\author{
Xianmin Jia \\ The College of Business Administration 1, Xi'an International University, Xi'an 710077, China \\ Tel: 86-29-8875-1604Ｅ-mail:jxmsxxa@126.com
}

\begin{abstract}
The actuality of the investments of transnational corporations in China is briefly described in this article, and the influences of the investments from transnational corporations in China are analyzed from two aspects, and the result indicates that in the process of attracting foreign investments, the active influence of the investments from transnational corporations should be fully utilized, and passive influences should be treated properly.
\end{abstract}

Keywords: Transnational Corporations, Investments in China, Influences

Since the reform and openness, Chinese economy has developed quickly, and the function of the investments of transnational corporations in China on the economy of China should not be neglected. Since 1993, China has been the developing country which continually attracts more foreign investments in the world, and especially since China entered into WTO, more and more transnational corporations enter into China, even in the background of global stagnant economy in 2009, the foreign direct investments in China still exceeded 90 billion dollars, and China only ranked after US, and became the second country in the world. When transnational corporations enter into China, they will bring advanced technologies, management experiences and many capitals, and they would continually increase the scale of the investments in China and extend the Industrial chain, which will certainly promote the development of Chinese economy. Of course, transnational corporations will also bring certain impacts to Chinese economy, such as depressing the development of national industry of China. The analysis of the actuality of the investment from transnational corporations and their influences on the national economy of China is very important to utilize the advantages and properly treat the disadvantages.

\section{The actuality of the investments of transnational corporations in China}

In thirty years from reform and openness, the investment scale of transnational corporations in China continually increased, and the foreign capitals actually used in China in 2008 achieved 92.395 billion dollars, a comparative growth rate of $23.58 \%$, and being the first position for 17 years in the developing countries. Up to the June of 2009 , there were 670 thousands foreign invested enterprises to be authorized by China, and 898.42 billion dollars had been actually used. In 500 largest global transnational corporations, 480 of them have invested in China or established the institutions, and the number of the R\&D centers established by these corporations has exceeded 980, which occupy over half number of Chinese R\&D institutions, and are continually developing.

As viewed from the actual use of foreign capitals, the transnational corporations from developed countries such as US and Japan occupies most share, and up to the late of 2008, the largest countries or regions which invested in China in turn were Hongkong, Singapore, Japan, US, Korea and Taiwan Province, and their accumulated investments had exceeded $70 \%$ of the national gross of foreign investments. As viewed from the invested industries, the industries invested in China by transnational corporations are mainly centralized in the manufacturing, the retailing, the information industry, the real estate and the business service, and these five industries have occupied above half of the total investments, and in 2006, the proportion of these five industries achieved $87 \%$ of the total invested project amount, and $80 \%$ of the total actual investment amount. As viewed form the invested region, the developed littoral cities are the main choices of transnational corporations, and because of some first mover advantages and regional advantages such as human resource and regional policy in the reform and openness, Beijing, Shanghai and other littoral developed cities centralized many transnational corporations, and Beijing, Shanghai, Jiangsu and Liaoning attract $68 \%$ of transnational corporations, but the middle and west regions have only a few of them.

\section{Active influences of the investments of transnational corporations in China to the economy of China}

After thirty years' development, the investments of transnational corporations in China, especially large transnational corporations, have occupied important status in the national economy of China, and been the important drive factor in the economic growth. 


\subsection{Increasing the capital sources and introducing the advanced technology, equipments and management mechanisms}

The intention of attracting investments and reforming and opening up is to compensate the deficiencies of capitals, technologies and equipments in the economic development, and study advanced management experiences of foreign enterprises. The practice has proved that the investments from transnational corporations are important capital source of China, and it could not only offer the short-term capitals for trading, production and debts, but the middle and long-term capitals for extending the production and renovating the equipments. These investments could not only lighten the press of deficient capitals in domestic large projects, but enhance the ability to introduce new business; could not only quickly form the actual production ability and assume the investment risk, but also increase the effective supply of the society. At the same time, transnational corporations are the main body to introduce technologies for Chinese enterprises all along. After 2005, the technology introduction of China increased quickly year by year. And in 2007, the technology introduction contracts were 9773 pieces in China, and the amount of these contracts achieved 25.42 billion dollars, a comparative growth rate of $15.6 \%$, and the capitals of the introduced technologies from foreign enterprises were 12.05 billion dollars, a comparative growth rate of $36.7 \%$, which occupied $47.4 \%$ of the total amount of the technology introduction of China. In addition, transnational corporations also brought more advanced management concepts and mechanisms, which could make for the transform of the management mechanism of domestic enterprises and the formation of the market economy.

\subsection{Extending the export channels of Chinese commodities and enhancing the export competition of foreign} trades

The durative growth of the export is the guarantee of the stable and durative growth of Chinese economy, and transnational corporations are the important power to driver the growth of the export of China. In 2004, the export amount of transnational corporations in China occupied 57\% (338.2 billion dollars) of the total export amount of China, and in 2007, this number had achieved 695.5 billion dollars, a comparative growth rate of $23.4 \%$. Comparing with domestic enterprise, transnational corporations have stronger export ability, and they make large contributions for the growth of export of China. Transnational corporations have their own global and perfect production channels and sales channels, which could not only help China to enhance the structure of the export commodities and increase the added values of production, but also utilize the global network system of transnational corporations in sales to increase the export and capital exchange, and accordingly increase the international repertory of China, and maintain the basic balance of international economic income and expenses.

\subsection{Offering large numbers of employment opportunities and accumulating human capitals}

The enterprises in China invested by transnational corporations could help China to absorb quite quantitative surplus laborers. With the increase of the number of these enterprises, the number of absorbed laborers increases year by year. According to the prediction, up to 2020, with the development of the economy and the increase of the investments from transnational corporations, 0.13-0.15 billion employment opportunities would be offered, which will be an important contribution for China being in the difficult employment situation for long time. Therefore, to some extent, transnational corporations could solve the difficult employment of China, and release the conflicts in the process of completely constructing the affluent society.

At the same time, the occupation training mechanisms with multiple direction and layers of transnational corporations will promote employees to grasp the modern skills and management knowledge, enhance their development opportunities, which would make for the accumulation of human capitals in the socialism construction.

\section{Challenges of the investments of transnational corporations in China}

In these thirty years, transnational corporations are not completely good for the development for the Chinese economy since they entered into the market of China. When we confirm their active influences, we must see the negative influences brought by them.

\subsection{Influencing the reasonable allocation of Chinese resources}

At present, the investments in China from transnational corporations have distorted the reasonable allocation of Chinese resources. To obtain larger economic benefits, most transnational corporations would select the industries with good economic benefits, and invest large numbers of capitals and advanced technologies, and attract other recourses such as labor forces and lands of China. In the conflict between the development and benefit, transnational corporations will largely influence the reasonable allocation of Chinese resources. Relative data indicate that in the direct investment of industry and the growth speed in recent years, the retailing, the 
service, the amusement, and some industries with better economic benefits all attracted many transnational corporations to invest in them. Especially for the real estate, the price of the real estate ascended continually in recent years, the comparative growth rate of $107.3 \%$ investment from transnational corporations increased the capitals in this industry. Comparing with that, the investments in the social welfare, the public establishment construction, the education, the public management and the social organization are much less.

3.2 Making against the reasonable establishment of the industry structure and the equal development among regions

The investment of transnational corporations would promote the updating of the industrial structure of China to some extent, and make the establishment of the total industrial structure of China to be unreasonable. To obtain the maximum profits in the investment, transnational corporations would continually adjust their own industrial structure, and keep the newest technology in their hands, and only offer relatively lower technology for China, which generate the singleness and subordinative property of the total industrial structure of China, and in addition, the unbalance of industrial distribution is more and more serious. As a whole, the industrial structure of foreign investments has many problems such as the regional distribution is too centralized, the technical layer is lower, and the general labor intensive manufacturing items are excessive, and the low-level repetitive introductions are still universal.

The unbalance of the region and industry of the investments in China from transnational corporations is one of cause to induce the unbalance of the regional and industrial economic development of China. Transnational corporations invest most capitals in the east regions, and bring new scientific concepts, and powerfully drive the reform and development of the national economy and the private economy in east regions, and its development step is obviously quicker than the middle and west regions, and they have been the main source of continually increasing finance taxation and incomes. But the middle and west regions have not these advantages, and the standard of living in these regions is still lower, and the regional economic development is still lagged, and after a long time, the gap of wealth in regions in China will be deteriorated.

\section{Conclusions}

Out of question, with the deep development of Chinese economy, more transnational corporations in the world will enter into China, which would bring not only infinite commercial opportunities for China, but also more austere challenges for Chinese economy and enterprises. Based on thirties years' experiences of the introduction of foreign investments, following aspects must be noticed. First, perfect laws and regulations, and create more perfect and ordered market competition environment and fair competitive conditions to attract more transnational corporations to invest in China. Second, correctly and reasonably instruct the regional selection and industrial distribution of the investments of transnational corporations. Third, actively support the domestic brands, protect the national industries, strengthen the core competitive force of Chinese enterprises, and encourage the transnational investments of Chinese enterprises.

\section{References}

He, Xiaoqin. (2006). New Trends of Transnational Corporations' Investments in China and Its Impact. World Economy Study. No.12. P.52.

National Bureau of Statistics of China. (2009). Statistical Communique of the People's Republic of China on the 2008 National Economic and Social Development. [Online] Available: http://www.stats.gov.cn/tjgb.

Shi, Haisheng \& Qian, Chenlin. (2007). Status Quo and Countermeasures to Multinationals Direct Investment in China. Chinese and Foreign Entrepreneurs. No.3. P.54.

Wang, Zhile. (2008). China Report of Transnational Corporations in 2008 (1st Edition). Beijing: China Economy Press. Feb of 2008. 